\title{
Popular War: Gauchos and the Challenge to Elite Power in Northern Rio de la Plata in the Revolutionary Period
}

DOI

http://dx.doi.org/10.1590/2236-463320151103

\section{Gustavo Paz}

Universidad Nacional de Tres de Febrero y Conicet/Instituto Ravignani - Argentina

\begin{abstract}
The War for Independence brought about popular mobilization in northern Argentina. As the war was waged in the provinces of Salta and Jujuy, rural population enlisted in militia battalions since 1814. Militia regulations in the Rio de la Plata area called for the extension of military jurisdiction (fuero) to all soldiers as well as for compensation when mobilized for combat. Popular mobilization in Northern Rio de la Plata posed a threat to elite power as it challenged long-held hierarchies and patterns of social deference dating from colonial times. Actions such as intimidation, seizure of livestock, and land occupations were commonly taken by gauchos and regarded by them as acts of social justice. The elite regarded them as arrogant and violent acts aimed at curtailing their power and strip them from their property and power.
\end{abstract}

\section{Resumo}

A Guerra da Independência provocou a mobilização popular no norte da Argentina. Logo que a guerra foi travada nas províncias de Salta e Jujuy, a população rural se alistou em batalhões da milícia desde 1814. Os regulamentos das milícias no Rio da Prata conclamaram na extensão da jurisdição militar (Fuero) seus soldados, e também uma compensação pela sua mobilização para o combate. A mobilização popular no norte de Rio de Prata representou uma ameaça ao poder da elite à medida em que desafiava hierarquias e padrões sociais estabelecidos de longa data desde os tempos coloniais. Ações como a intimidação, a apreensão de gado, e as ocupações de terra foram comumente tomadas pelos gaúchos como atos de justiça social. A elite via-as como atos arrogantes e violentos que visavam cercear seu poder e tirá-los de propriedade e poder.

Keywords

War-Rural Mobilization-Militia-Fuero-Tenancy-Gauchos 

PAZ, José María. Memorias póstumas del General José María Paz, Madrid: Editorial América, n.d., p.452.

2

On Guemes' and his government see the memoirs of two of his political opponents, URIBURU, Dámaso de. "Memorias," in Biblioteca de Mayo. Colección de Obras y Documentos para la Historia Argentina. Memorias, Autobiografias, Diarios y Crónicas, Buenos Aires: Senado de la Nación, 1960, vol. I, p.720-721; GORRITI, Juan Ignacio: "Autobiografia politica," in VERGARA, Miguel Angel (ed.). Papeles de Gorriti, Jujuy, 1936, p.53-55. Modern works include FRIAS, Bernardo. Historia del General Martín Miguel de Güemes y de la Provincia de Salta, o sea de la Independencia Argentina [1902], Buenos Aires, Plus Ultra, 1972, and CORNEJO, Atilio. Historia de Güemes, Salta, 1940.

3

For the classic approach to the study of caudillismo see WOLF, Eric and HANSEN, Edward, "Caudillo Politics: A Structural Analysis," Comparative Studies in Society and History 9(2), 1967, p.168-179, and LYNCH, John Lynch. Caudillos in the Hispanic World, 1800-1850, Oxford: Oxford University Press, 1993. Their approach has been rightfully criticized by SAFFORD, Frank. "The Problem of Political Order in Early Republican Spanish America," Journal of Latin American Studies 24 (Quincentennary Supplement, "The Colonial and Post-colonial Experience"), 1992, p.90-92. For recent studies of caudillismo in Latin America see CHASTEEN, John Charles Chasteen. Heroes on Horseback. A Life and Times of the Last Gaucho Caudillos, Albuquerque: University of New Mexico Press, 1995, DE LA FUENTE, Ariel. Children of Facundo. Caudillo and Gaucho Insurgency During the Argentine State-Formation Process, Durham: Duke University Press, 2000, and GOLDMAN, Noemi and SALVATORE, Ricardo (eds.). Caudillismos Rioplatenses. Nuevas miradas a un viejo problema, Buenos Aires: EUDEBA, 1998

For analyses of Güemes political system see HALPERIN DONGHI, Tulio. Revolución y guerra Formación de una elite dirigente en la Argentina criolla, Buenos Aires: Siglo XXI, 1972, p.274-278, and his"El surgimimento de los caudillos en el marco de la sociedad rioplatense postrevolucionaria," Estudios de Historia Social 1, 1965, p.122-127. A recent study is MATA, Sara Emilia. Los gauchos de Guemes. Guerras de Independencia y conflicto social, Buenos Aires: Sudamericana, 2008.

5

On caudillos and charisma, a topic generally neglected by modern historians but which did not remain unnoticed to writers contemporary to the events, see CHASTEEN, Op.Cit, p.5.

6

This recent literature is too vast to cite; an excellent overview in English is GARAVAGLIA,
In his memoirs, written in exile in the 1840s, General José María Paz, a military hero of the independence war described the political system imposed by militia commander Martín Güemes in the northern provinces of the Río de la Plata as follows,

Everyone knows that this caudillo, getting his support exclusively from the plebe and gauchos of the rural areas, had made enemies of the other superior classes of society. ${ }^{1}$

This brief paragraph sheds light on the Salta and Jujuy urban elites' deepest dilemma: the challenge to their power by popular mobilization. The cabildo of Salta elected Güemes governor of the province in 1815 hoping that he would lead a victorious campaign against the Spaniards. This Güemes did, but he also inaugurated a political regime that posed a threat to the very survival of the elite that had elected him. Since 1814, the course of the war forced the elite to tolerate popular mobilization needed to stop the Spanish frequente invasions. But mobilization, in turn, transformed the rural population into a powerful political tool against elite government. ${ }^{2}$

The key to understand the elite's conundrum is the relationship established between Güemes and his rural following. Güemes built up his power by offering protection to the rural population who became his supporters. ${ }^{3}$ Güemes extended his protection applying legislation that granted militia men the full rights of "fuero militar" (military jurisdiction), thus excluding them from the jurisdiction of civil authorities. This was a major blow to the cabildos of both Salta and Jujuy who hitherto had exerted their unchallenged authority over both city and country people. Also Güemes offered his men compensation for military service. He resorted to the radical --subversive for the elite-- measure of suspending the collection of rent from tenants enrolled in militia regiments. This hit the elite at the core of their economy: with the decline of trade with Upper Peru due to the war, agriculture and tenancy were their two only remaining profitable sources of income.

Thus Güemes broke up old, colonial bonds between landlord and peasant based on tenancy and peonage and inaugurated a new brand of loyalty between caudillo and rural population that challenged elite domination. ${ }^{4}$ To this Güemes added the unmistakable appeal of a charismatic personality: he was worshipped by his followers who considered him a father-like figure. ${ }^{5}$

\section{Who were the Gauchos?}

In the last thirty years historians of rural life of late colonial and early independent Río de la Plata have challenged the image hitherto held true of a countryside inhabited by gauchos roaming the extended pampas in search of occasional and unstable work in large cattle ranches. By putting their finger on the issue of agrarian production and labor, these historians have conveyed a picture of the Buenos Aires countryside --and to a certain extent of all the littoral provinces-- inhabited by small agricultural producers whom they call "peasants." In this renovated depiction of the rural areas, the gaucho in the traditional sense of the word seems to have had a marginal presence in the pampas. ${ }^{6}$

But in Argentina there were other gauchos: those who fought a fierce "guerra gaucha" against the Spaniards in Salta and Jujuy. Previous 
Juan Carlos and GELMAN, Jorge D., "Rural History of the Río de la Plata: 1600-1850. Results of a Historiographical Renaissance," Latin American Research Review 30 (3), 1995, P.75-105

7

For instance, in December 1813, on the verge of the second Spanish invasion, the cabildo of Jujuy asked the Lieutenant Governor to release the "labradores" enlisted to guard the city, as the time to harvest wheat and sow maize was approaching; the official complied with the cabildo's request, ROJAS, Ricardo (ed.). Archivo Capitular de Jujuy, Jujuy, 1913, [AC] 11 December 1813, II, p.91-92. Other examples of such requests, in these cases specifically of "arrenderos" (tenants) may be found in AC, 3 April and 14 September 1813, II, p.57-58, and 79.

8

ROJAS, Ricardo, "La patria en Jujuy," AC, II, XLVII-XLVIII, CONI, Emilio A., "Los distintos significados del vocablo 'gaucho' a través de tiempos y lugares," Boletín de la Academia Nacional de la Historia XV, 1941, p.309-330. Both of them quote MITRE, Bartolomé. Historia de San Martín y de la emancipación americana, Buenos Aires, 1887, I, 263-264.

CONI, Op.Cit, p.313. Coni argues that the word "gaucho", common in the littoral provinces of the Río de la Plata, was carried to the Northern provinces by the porteño soldiers of the Army of the North. As they found the rural population there similar to the one they had fought against in the Banda Oriental under José Artigas' orders, whom the soldiers called "gauchos", they readily applied the term to the northern peasants in arms.

10

Archivo General de la Nación [AGN], X-5-7-4, "Acta Capitular del Cabildo de Salta, enviada al Director Supremo," Salta, 29 October 1814.

11

URIBURU, Op.Cit., p.700-701. See also PAZ, Op.Cit., p.226. to the revolutionary period the name "gaucho" had never been heard in these Northern provinces. Whenever the local authorities refer to the rural population they called them "paisanos," "labradores," or more generally "habitantes de la campaña."

The first mention of the term "gaucho" dates from February 1814. General José de San Martín, Commander in Chief of the Army of the North, informed the central government in Buenos Aires that the "gauchos" of Salta were waging a war of resources against the invading Spaniards. When the official newspaper La Gaceta Ministerial published the piece in April, its editors substituted "brave peasant patriots" for "gauchos" because it was afraid of the negative impact of the term on its porteño (i.e. Buenos Aires) readers. ${ }^{8}$ In fact, according to Emilio Coni, in Buenos Aires, the littoral provinces, and Banda Oriental, "gaucho" had a twofold meaning: one restricted to rural people of unknown occupation or criminals, and the other one encompassing all the inhabitants of the countryside. ${ }^{9}$

The name "gaucho" started to become common in Salta and Jujuy during the second Spanish invasion in 1814. In October 1814 the cabildo of Salta informed the Director Supremo of the recent disastrous defeats of the revolutionary Army in Upper Peru. The Army of the North was in complete disarray and was unprepared to defend Salta and Jujuy from the impending invasion of the Spanish Army. Both provinces would have been doomed if the rural population had not reacted as they did. In a very telling statement the cabildo of Salta praised the "citizens of the countryside" as they took up arms against the Spaniards,

\footnotetext{
Strange prodigy! A sole spirit encouraged all these peoples, who we did not deem enlightened enough to make such a general, magnanimous, and heroic decision. It is well known that the only riches these miserable people had were a short number of cattle and horses. Ready to wage war, with no weapons besides their own arms, there has not been a single man who has not enlisted as a volunteer soldier, who served under the name of Gauchos. As they were not regular soldiers, since they took sides they became aware of the perils of war and neglected their own existence, and even the means to keep their affairs and homes. ${ }^{10}$
}

The cabildo had to clarify the meaning of the word "gaucho" in its statement, as the term was new to the language of the district: Gaucho meant rural people of short material means who rose up in arms voluntarily and enlisted as informal soldiers.

During the Spanish occupation of Salta and Jujuy in the first half of 1814, the Spaniards frequent raids into the countryside to seize forage and food prompted rural mobilization. The Spanish troops stationed in both cities occupied neighboring haciendas and ransacked others. Restricted to the landowners' assets at first, the Spaniards' pillage did not spare the rural poor. Dámaso de Uriburu, eyewitness to these events, wrote in his memoirs that Spanish Commander General Joaquín de la Pezuela

extended proscription, pillage, and death to the mass of the population of the countryside, who hitherto had been only spectators not in the least interested in the war...harassed and treated cruelly without motive, they resolved to rise up en mass to defend their lives and belongings, so unfairly and pointlessly threatened.11

Mobilization of the rural poor was both spontaneous and organized. In the first case, groups of peasants voluntarily formed squadrons and elected their leaders. Dámaso de Uriburu mentions several skirmishes 
GARCÍA CAMBA, Andrés. Memorias del General García Camba para la historia de las armas españolas en el Perú, 1809-1821, Madrid: Editorial América, n/d, I, p.314-315.

15

GARCÍA CAMBA, Op.Cit., p.326, 333, 338-339, Paz, Op.Cit., p.226, GRAANER, Jean Adam. Las Provincias Unidas del Río de la Plata en 1816 (Informe dirigido al Príncipe Bernadotte) [1817]. Buenos Aires: El Ateneo, 1949, p.72-73.

16

For description of the gauchos' guerrilla tactics see GARCÍA CAMBA, Op.Cit., I, p.326, 341, 343344, URIBURU, Op.Cit., p.704, PAZ, Op. Cit., p.359, p. $455-456$.

Paz, Ibidem, p.266, 344. among such groups and the Spaniards in the vicinity of Salta. On one such occasion, the people were celebrating carnival when were suddenly attacked by the Spaniards. Summoned by a "curandero" (folk-healer), a man of high prestige in the locality, they grabbed clubs, ploughs and other tools and fought back. ${ }^{12}$ In the second case, the landowners organized rural mobilization. As a response to the pillaging by Spanish troops, several "hacendados" recruited their tenants and peones and formed militia battalions. ${ }^{13}$

When General San Martín put Güemes in charge of the rural militia of Salta and Jujuy popular mobilization had already started to organize. Güemes' main task was to expand and discipline the troops. He managed to extend militia recruitment to every corner of the province by drawing into this process more landowners and also minor rural officers such as post-masters. By 1815, when he was elected Governor, he already was the chief of a force of some 3,000 soldiers.

Güemes favored the use of the term "gaucho" to refer to the rural militia. The gaucho was, from then on, a peasant turned soldier. According to Spanish General Andrés Garcia Camba the gauchos

\section{[W]ere country folk, good riders armed with machete, saber, musket or rifle, which they used, mounted on their horses with unsurpassed skill. They approached the enemies with surprising confidence, ease, and in such cold blood as to amaze the European officers that saw these extraordinary horsemen for the first time, whose unmatched talents for guerrilla warfare they repeatedly tested. ${ }^{14}$}

Gauchos were compared to the Cossacks and Mamelucs in their outstanding riding skills. As Garcia Camba put it (with a little exaggeration) "these horsemen need not dismount to undress a corpse or to grab a silver coin from the ground." Güemes was also said to be a "most excellent gaucho, a great horseman." 15

Gauchos also achieved a strong reputation -- among both friends and foes of the revolutionary cause-- for being consummate practitioners of guerrilla warfare. They knew that in open battle against better armed Spanish troops they were doomed. Thus, they resorted to torturing the Spaniards with sudden skirmishes in the middle of the night held in locations in the countryside suitable to this hit-and-run strategy. The gauchos were masters at hiding themselves from the Spanish troops until they got close to them and attack them ferociously. Besieged within the confines of the cities of Salta and Jujuy, the Spaniards found it extremely difficult to venture out to get food and forage. Every time they did they were systematically harassed by the gauchos. ${ }^{16}$

Salta and Jujuy owed to the gauchos' "war of enthusiasm," as General Paz called it, their victory over the Spanish Army in mid 1814. Paz recalls in his memoirs that victory gave the gauchos a measure of their military might and a sense of pride. He also pointed what he considered the gauchos' most negative traits: they were unruly, undisciplined and arrogant. Once, he censured a fellow officer for yelling telling him that "we [the military] are not gauchos, we do not yell." 17

Thus, by the end of the second Spanish invasion in mid 1814, "gaucho" was an established term in the vocabulary in the Northern provinces of the Río de la Plata.

Who were these rural poor turned into soldiers? The few available contemporary sources helpful to estimate the size of the gaucho militia are military rolls, which merely contain names, ranks, and attendance. Only 
The Archivo Histórico de la Provincia de Jujuy [AHPJ] provided the only remaining military censuses. I was not able to find any similar documentation on Salta.

19

For details see PAZ, Gustavo L. "La rebellion de los gauchos: movilización campesina en el norte argentine durante la Guerra de independencia," in FRASQUET, Ivana (ed.). Jamás ha llovido reyes del cielo... De independencias, revoluciones y liberalismos en lberoamérica. Quito: Universidad Andina Simón Bolívar, 2013, p.194-208.

20

MADRAZO, Guillermo. Hacienda y encomienda en los Andes. La puna de Jujuy bajo el Marquesado de Tojo, siglos XVII-XIX. Buenos Aires: Fondo Editorial, 1982; MATA, Sara. Tierra y poder en Salta. EI noroeste argentino en visperas de la independencia Sevilla: Diputación de Sevilla, 2000

Archivo Histórico y Biblioteca de Salta (AHBS), 1822, "Arrendamiento de los Gauchos."

\section{2}

See Tulio Halperin Donghi's remarks on the importance of provincial elites' mechanisms of appropriation of agricultural surplus by supplying credit to the peasants in his "The Buenos Aires Landed Class and the Shape of Argentine Politics (1820-1880)," in HUBER Evelyn and SAFFORD, Frank (eds.). Agrarian Structure \& Political Culture. Landlord \& Peasant in the Making of Latin America. Pittsburgh: University of Pittsburgh Press, 1995, p.40.

23

For further analysis of these cases see my dissertation, Paz, Province and Nation, chapter 4. A small sample of these judicial documents: Archivo de los Tribunales de Jujuy (ATJ), 79/2580, 1823, "Testamento del Sr. Coronel Don Bartolomé de la Corte;" ATJ, 77/2483, 1818, "Expediente sobre los vienes del finado Juan Bautista Solís;" ATJ, 78/2514, 1821, "Inventario de Marcos Toledo en San Pedro." in 1826, when the militia was reorganized the provincial government took more complete military censuses. ${ }^{18}$

In 1826 gauchos encompassed roughly ten per cent of the total population of the province. As one of the main goals of the provincial government's reorganization of the militia in 1826 was to reduce its size, its number and ratio to the total population must have been larger during the war of independence. Almost three quarters of the gauchos were between 20 and 35 years of age, and two thirds of them were married and were likely to have families. Only one military census (León, an agricultural district located immediately north of the city of Jujuy) recorded gauchos' ethnicity and occupation. All of the sixty eight men enlisted there were "natives," that is to say Indians and all of them but one were "labradores," or agricultural workers. Except for one who lived on his own land, all of them lived in haciendas owned by members of elite families of Jujuy. A large majority of the gauchos of León were born within the province, most of them in districts nearby, and only twenty of them were foreign born in neighboring Upper Peru and Peru. ${ }^{19}$

Thus, gauchos were adult men living in haciendas, the majority of whom were married and had families. Their working conditions in the haciendas varied from district to district, but the information on these arrangements is very scarce. In the haciendas of Salta and Jujuy, however, tenancy and peonage were the most common labor arrangements between landlords and peasants since at least the eighteenth century. ${ }^{20}$

In Jujuy and Salta tenancy (called "arriendo y obligaciones") involved mutual obligations between landlord and tenant. Tenants used to pay the landowner a fixed amount of money a year, usually between six and twelve pesos, depending on the size of the plots assigned. In addition to this, they had to work for the hacienda two weeks a year tending the landlord's livestock, branding cattle or shoeing horses. Sometimes the landowner provided the tenant with seeds, agricultural tools (a plough, for instance), and oxen, and collected the rent in kind (i.e. a share of the crop) instead of in money. ${ }^{21}$

The relationship between tenants and landowners involved many more complex transactions than the mere payment and collection of rent. It also included trade and credit relations. For tenants and peasants in general, the landowners' (and merchants') shops in town were a source of goods purchased on credit, while for the merchants and landowners the supply of credit to the peasants was another way to put their hands on the agricultural surplus, besides the collection of rent. ${ }^{22}$

Many judicial cases held in the local archives reveal the intricate web of social and economic relationships established among peasants and the powerful within the local society. These documents also expose the complex social meaning imbedded in the word "gaucho" in the countryside of Jujuy and Salta. If only a few of the gauchos owned land, it is apparent that the upper echelons of them owned livestock. They were also able to participate in commercial activities, and in some cases were key employees within the structure of a hacienda. ${ }^{23}$ These cases, of course, are not a representative sample of the local rural society as they do not include the poorest tenants and peons who did not file any suit.

To sum up: in Salta and Jujuy, gauchos were men of the countryside of scarce material means, at least to the eyes of the elite. Landless people, they were either peons or tenants on the estates of the elite paying rent 
and/or working for the landowners. Sometimes engaged in commercial activities, some of them also owned livestock. The word had an unmistakable military connotation: gauchos were horsemen enlisted in the militia.

\section{Caudillo and Gauchos: Protection and Compensation}

24

AGN X-27-8-11, Güemes to Commander Juan Franciso Pastor, Puerta de Dios, 27 April 1817, in "Testimonios de certificaciones, Oficios superiores, de méritos y servicios Patrióticos del Ciudadano Juan Francisco Pastor, Comandante de Banguardia y Alcalde Pedaneo del Pueblo de Umaguaca: contraidos desde el año de 1810," f. 9.

GULLÓN ABA0, Alberto. La Frontera del Chaco en la Gobernación del Tucumán (1750-1810). Cádiz: Universidad de Cádiz, 1993. For an excellent explanation of the legal issues involved in military fuero see MCALISTER, Lyle. The "Fuero Militar" in New Spain, 1746-1800. Gainsville: University Presses of Florida, 1957

27

AGN, IX-34-2-5, Expediente 2510, 1800, and X-23-4-7, Expediente 164, 1801, "Peticiones de D. Julián Gregorio de Zegada, Síndico Procurador de Jujuy."
[I want] to thank you a million times for your constant and distinguished services... Please extend my most sincere gratitude to all of the worthy officers who have excelled along with you, especially to Lieutenant Ximenes of whom I have the best references...let him rest assured that I take him under my protection; I will reward him and the others like him according to their services. ${ }^{24}$

Protection and compensation are key factors to understand the bond established between Güemes and the gauchos. In his letter to Gaucho Commander Juan Francisco Pastor, chief of the militia of Huamahuaca (Jujuy), Güemes pledged to extend his protection to all the gauchos who were loyal to the cause of independence and to reward them.

Güemes established a direct relation between him and the gauchos by extending his protection over them and by giving them material compensation for their services. He extended military jurisdiction (fuero militar) to all of the gauchos enlisted in the militia by which they were placed beyond the jurisdiction of civil authorities. Güemes also declared the gauchos exempt from rent payment to their landlords while in service. His bond with the gauchos circumvented traditional ways of elite control of the peasants, such as cabildo jurisdiction over the countryside and the extraction of economic surplus via rent. By doing this Güemes enraged the elites of Jujuy and Salta, as he not only built up military regiments under his personal control but also stripped the elite of their political power and economic and social control over much of the rural population. As Dámaso de Uriburu, one of his most formidable opponents put it

His [Güemes] ruling style corresponded exactly with an early plan he designed to establish an independent sovereignty in the province of Salta... [He] instilled in the irregular militia interests that were new and different from those of the community, and made it an obedient instrument for his plans. ${ }^{25}$

The question of extending military jurisdiction to the rural militia had colonial roots in Jujuy and Salta. As both cities bordered the Indian territory of Chaco, raising rural militia to defend the eastern frontier had always been a major concern. Throughout the eighteenth century colonial authorities controlled the Indian frontier with professional military regiments, called "partidarios." A force of some two hundred men, they were stationed in the several forts scattered along the frontier. Partidarios enjoyed full military jurisdiction, in both civil and criminal cases. ${ }^{26}$

Partidarios received the occasional help of militia recruited locally among the rural population in cases of Indian attacks. In such cases, the cabildo had the right to recruit rural population (around six hundred men), enlist them for one or two months, and assign them to guard the forts on the frontier while the partidarios were fighting the Indians. These arrangements were resisted by local landowners who complained that militia recruitment in times of harvest and sowing created a labor shortage on their haciendas. ${ }^{27}$

In 1801 Viceroy Marquis of Avilés enacted a "Reglamento" regulating the duties and rights of the militia while enlisted. Their main task was to 
"Reglamento para las milicias disciplinadas de infanteria y caballeriadel Virreinato de Buenos Aires (14 de enero de 1801)," in ARCHIVO HISTÓRICO DE LA PROVINCIA DE BUENOS AIRES. Cedulario de la Real Audiencia de Buenos Aires, La Plata: AHPBA, Vol. 3, 1938, p.81-116

29

"Reglamento," Chapter IV, Articles 1, 8. 30

AGN, IX-23-4-7, Royal Accord, 25 April 1801.

31

Quoted in GULLÓN ABA0, Op.Cit., p.289.

32

On this problem see PAZ, Gustavo L., "'El orden es el desorden'. Guerra y movilización campesina en la campana de Jujuy, 1815-1821," in FRADKIN, Raúl and GELMAN, Jorge (eds.). Desafíos al orden. Política y sociedades rurales durante la Revolución de Independencia. Rosario: Prohistoria, 2008, p.83-101.

33

"Estatuto Provisional para dirección y administración del Estado, dado por la Junta de Observación (5 de mayo de 1815)," in CAILLETBOIS, Ricardo (ed.). Estatutos, Reglamentos y Constituciones Argentinas (1811-1898). Buenos Aires: UBA-FFyL-Instituto de Historia Argentina, 1956, p.53-55.

AC, 26 August 1815, II, p.132-141. collaborate with the partidarios in the surveillance of the Indian frontier. The "Reglamento" created four militia cavalry squadrons in Salta and Jujuy, with 1,200 soldiers. ${ }^{28}$ Among its main clauses it included the militiamen's right to enjoy full military jurisdiction and payment while enlisted. ${ }^{29}$ To appease the landowners a Royal Accord prohibited the recruitment of peasants in times of harvest. ${ }^{30}$

Military jurisdiction became one of the most polemical aspects of the recently created militia. The cabildos complained to the Intendents about the many instances of disorder created by the extension of the "military fuero" to the militiamen. They singled out the fact that militiamen were not forced to comply with cabildo ordinances or "bandos de buen gobierno." Shortly after the "Reglamento" was in place, the cabildo of Salta asked the Intendent to scale down the extent of military fuero to only the times when the militia were on actual service in the frontier. The Intendent refused to do so as he deemed the privileges granted by military fuero to be the only incentive for rural people to enlist in the militia. Even royal officers complained to the Viceroy that "fuero" prompted militiamen to be more unruly as it put them beyond the reach of ordinary justice. As future Intendent Arrigunaga put it in 1806, "fuero sounds in the ears of the militia man like independence from ordinary jurisdiction." ${ }^{31}$

When Güemes organized the Salta and Jujuy militia in 1814 he applied the existing late colonial legislation on the subject. Thus, militia men enjoyed military jurisdiction and were entitled to monetary compensation for their service. But the circumstances of the war of independence made the institution radically different from that of colonial times. First, most of the male rural population of the province was recruited into the militia after the second Spanish invasion of 1814, and second, the financial resources of the province were insufficient to cover the expenses generated by militia mobilization. At stake was not only the issue of the extension of fuero to every peasant enlisted in the militia but also the availability of rural workers in the haciendas. In fact, one of the major consequences of massive enlistment of gauchos since 1814-1815 was a sharp labor shortage in the countryside. ${ }^{32}$

New legislation drafted by the central government in 1815 introduced a major change in the organization of militia. The Provisional Statute recognized two types of militia, one provincial ("milicias provinciales"), another urban ("milicias cívicas"). The statute applied the viceregal "Reglamento" of 1801 to all of the aspects related to the provincial militia, but issued new legislation regarding the urban ones. They would be under the command of the cabildos, and only veteran soldiers enlisted would enjoy military jurisdiction. ${ }^{33}$

In August 1815 the cabildo of Jujuy met to revise the new statute issued in Buenos Aires. The revisions proposed included the provisions on militia. The cabildo objected to the application of the Reglamento of 1801 to the militia recruited by Güemes to fight the Spaniards. The cabildo recommended a change of status for the militia that would define them as "civicas" instead of "provinciales". The militia thus defined would not enjoy military jurisdiction and would be under the cabildo's control. ${ }^{34}$

In the midst of a political strife between Güemes and the cabildo of Jujuy (who resisted his election as governor by the cabildo of Salta without Jujuy's participation), in early March 1816 the Commander of the urban militia of Jujuy reported to the cabildo that Güemes had summoned his company of civicos thus disobeying the regulations on the matter included 
35

AC, 4 March 1816, IV, p.199.

36

"Estatuto Provisional dado por la Junta de Observación y aprobado con modificaciones por el Congreso (22 November 1816)," in CAILLET-BOIS, Op.Cit., p.94-95.

37

"Auto de Güemes sobre la perpetuidad del fuero militar correspondiente a sus escuadrones de Gauchos," 11 April 1818, in GÜEMES, Luis (ed.). Güemes documentado. Buenos Aires: Plus Ultra, 1972, vol. 7, p.441.

38

GÜEMES, Ibidem, vol.7, p.441-442.

"Oficio del Cabildo de Salta a Güemes," 5 August, 1815, in GÜEMES, Op.Cit., vol.7, p.445-446.

in the 1815 Statute. Confronted by the cabildo on the issue, Güemes replied that he had decided to incorporate all the inhabitants of Jujuy, both city and countryside, into the gaucho militia "as a result of the high reputation the gauchos had achieved among the enemies, and to avoid any misconduct." After a heated conflict between Güemes and the cabildo, the governor decided unilaterally to extend military jurisdiction to all the militia, urban and rural and put it under his sole command. Güemes fumed that

[N]owhere in the world were people from the countryside part of the urban militia; [I] decided that all of them should enlist in the heroic companies of the Gauchos, and that this arrangement will be forever..$^{35}$

In 1817 a new Estatuto Provisional issued by the Congress confirmed the provisions on militia contained by former legislation. ${ }^{36}$ In Salta and Jujuy there were rumors that the new law had discontinued military jurisdiction for the gauchos. To stop the rumors, Güemes hastened to issue a decree confirming the inclusion of gauchos in fuero militar. He stated that

[A]II the gauchos enlisted in their respective squadrons and troops enjoy and will for ever enjoy military fuero, and also whatever privileges the Supreme Government bestows upon them in gratitude and as reward. ${ }^{37}$

Soon afterwards, the head of the State, Director Supremo Juan Martín de Pueyrredón confirmed Güemes' concession of military jurisdiction to the gauchos as it complied with the legislation on the matter, namely the "Reglamento of Militia" of 1801 and the Estatuto of $1817 . .^{38}$

As a result of the extension of military jurisdiction to all gauchos, a sizable part of the rural population of Salta and Jujuy achieved a privileged legal condition because of their participation in the war of independence. Being men enlisted in militia squadrons, gauchos were beyond the cabildos' civil jurisdiction. As the cabildo of Salta so ably --and desperately-- put it

The current circumstances demand that any Americano should be a soldier, and perform his service whenever needed; but when he is not in service, he is a paisano, and so immediately subjected to civil jurisdiction. If this wise and prudent measure is not observed, let us do away with ordinary judges so that they do not become ghosts with jurisdiction but with no subjects to judge upon. ${ }^{39}$

In 1817, the elite of Salta and Jujuy received yet another blow from Güemes. According to the "Reglamento" of 1801 militia men were to be compensated for their services while mobilized. As the provincial treasury was exhausted by the efforts of a war that was waged increasingly paid for by local resources, Güemes decided to exempt the gauchos from the payment of rent to the landlords as compensation for their services.

This controversial decision opened a new gap between Güemes and the urban elite of both Jujuy and Salta. The exemption of gauchos from rent payment hit the elite hard. As the war had halted trade with Upper Peru and Peru their sources of income were limited exclusively to their landed wealth. Dámaso de Uriburu described the situation as follows

Güemes proposed a sort of agrarian law by which he stripped the large majority of landowners of the province of their possessions as he exempted the gauchos from paying rent to the owners of the lands they occupied. So, these [the gauchos] became owners of almost all the territory of the province. 
40

URIBURU, Op.Cit., p.734

For details on this see PAZ, Gustavo L., "Reordenando la campaña: la restauración del orden en Salta y Jujuy, 1822-1825," in FRADKIN, Raúl 0. (ed.). ¿Y el pueblo dónde está? Contribuciones para una historia popular de la Revolución de independencia en el Río de la Plata. Buenos Aires: Prometeo, 2008, p.211-216.
AHBS, "Arrendamientos," passim.
Uriburu added that the gauchos "guided by a traditional loyalty to their old "patronos" "refused the privilege of exemption and kept on paying the rent." ${ }^{40}$ Uriburu's opinion notwithstanding much evidence points to the fact that gauchos did indeed stop paying rent to their landowners during Güemes' tenure as governor. ${ }^{41}$

The exemption from rent payment was a pressing issue for the landowners. Immediately after Güemes' untimely death in mid-1821 they started to complain about it repeatedly to the provincial government. In 1822 a newly elected governor, José Ignacio Gorriti ordered a thorough survey to settle the matter.

The government consulted the Commanders of the militia throughout the province to determine whether Güemes had indeed exempted gauchos from rent payment or not. Of the ten Commanders who answered the survey, all but two (who were enemies of Güemes) agreed that the former governor had definitely granted the exemption to the gauchos. Some stated that he had exempted the gauchos only when they were effectively on duty; others, on the contrary, said that the exemption encompassed all gauchos at all times. Two of them very clearly pointed out that the distinction was negligible as the gauchos served year round because of the frequent clashes with the Spanish troops.

Those who agreed about the fairness of the exemption justified it as a reward. Calling the gauchos "the arms of the Revolution and the war" of independence in Salta, Commander Juan Manuel Quirós, a close collaborator of Güemes, asked

What arms have we used to accomplish these feats? Anyone who would not fail to show some gratitude must confess the Gauchos have had a very active role in the glories and triumphs of America... They are very poor in possessions, but very rich in merit.

Asked if the government should abolish the exemption, almost all of the Commanders strongly rejected the idea. According to them abolishing the exemption would only bring chaos in the rural areas because, as Commander Francisco Velard reported,

[i]f they [gauchos] are forced to pay rent it will terminate a privilege they hold as unquestionable justice. ${ }^{42}$

During his tenure as Governor, Güemes moved from a Commander of the provincial militia to a caudillo. He succeeded in mobilizing the rural masses of Salta and Jujuy to fight for independence. More than anything else, he succeeded in creating a powerful and fearsome militia of gauchos with whom he established a new type of bond, that between caudillo and follower. This new bond both superseded and replaced the traditional one between peasant and landlord based upon the elite's monopoly of land ownership and credit. The protection Güemes granted the gauchos by extending fuero militar freed them from elite control by placing them beyond the jurisdiction of the cabildos. Also compensation to militia freed a large portion of the rural population from the centuries-old demands of the elite, namely from payment of the rent. Thus, it is not surprising that the gauchos started to call Güemes "our protector," and "father of the poor." 
43

GORRITI, Op.Cit., p.53.

AHPJ, Zegada Family Papers, 17 March and 27 November 1815.

45

AGN, VII, Teodoro Sánchez de Bustamante Papers [TSB], II (no date, but probably 1822), p.98.
Challenging Elite Power

Between 1815 and 1821 the consolidation of Güemes' power brought what to most members of the elite amounted to political persecution exercised at two levels. First, the exclusion of Güemes' opponents from public office challenged elite's power at its core, for they were barred from both the cabildo and the city's representation before Congress; second, the imposition of forced contributions and confiscation of property threatened the elite's material survival.

The elite's real threat however came from the actions of the gauchos. Writing in the mid-1830s as a political exile in neighboring Bolivia, Juan Ignacio Gorriti (a prominent priest and politician from Jujuy) reflected on gauchos' challenge to elite property and authority in these alarming terms,

\begin{abstract}
All the properties in the countryside, lands and livestock alike, were subjected to pillage. The vecinos would complain against the theft, violence, and plunder they suffered at the hands of the gauchos, but all in vain. Each [gaucho] commander was the absolute ruler of his district, and each [gaucho] soldier followed the example of his Chief... Stabbings and murders were committed with impunity. Everything was allowed provided that when the Spanish army invaded the Province they [the gauchos] would defend it. ${ }^{43}$
\end{abstract}

Beginning in 1815, the gauchos began to ransack the elite's haciendas and seize cattle and horses. Güemes and the gaucho commanders deemed it just that the gauchos have access to the landowners' livestock, seeing it as the elite's small contribution to the independence cause contrasted with the gauchos risking their lives for it. The landowning elite were outraged at the loss of property. Although Patriot armies had lived on their lands since the beginning of the revolution, confiscation of livestock was resented for the militia commanders, unlike the regular Army officers, refused to give the landowners receipts for the animals seized. Timing also accounted for the elite's rage. The decline of trade and the exemption of rent payment by the gauchos had made the elite rely even more heavily on their livestock for their sustenance.

Protected by military fuero, the gauchos entered the elite haciendas freely, and took livestock with them. Several landowners reported that gauchos' "pillage" of cows and horses was fairly common in their lands. ${ }^{44}$ Landowner Manuel Ignacio del Portal blamed Güemes for the ruin of his haciendas for he had authorized his Commanders and gauchos "to take anything they needed for the supply of the troops that defended this Province" without giving the landowner any receipt or even an account of whatever they took. ${ }^{45}$

If at the beginning the gauchos distinguished haciendas belonging to royalist from those belonging to patriots, the difference disappeared quickly. After a short time all haciendas became subjected to raids. Moreover, Güemes political opponents later claimed that the caudillo had his gauchos raid their haciendas with thorough fury simply because they opposed his politics.

In 1816, when Bustamante left Jujuy to join the Congress of Tucumán as representative, he owned many livestock extant on his estate "El Brete", one of the richest haciendas in the surroundings of Jujuy. Bustamante reminded the governor --by then the anti- Güemes General Antonio Alvarez de Arenales-- that the gauchos had entered the hacienda many times to seize cattle and horses and left it depleted of cattle. 
AGN, VII TSB, III, 138. In 1829 the province of Salta acknowledged Bustamante's impending debt for 4,000 pesos.
47

AGN, VII, TSB, I, 28, "Sumaria Información jirada sobre la denuncia contra el Dr. Teodoro Sanchez de Bustamante por el Sargento de la 10 Compa. del Rejimiento de Caballeria de gauchos Franco. Santa Ana y segun el decreto librado a la Sargentía Mayor del Cuerpo por el Sor. Comandante General Coronel Dn. Martín Güemes, Jujuy, Febrero de 1816," f. 2-2v, 6-6v.
More than the goal of these exactions --namely, to support the gauchos who were fighting for independence-- Bustamante objected to the methods applied. He claimed that Güemes ordered the Gaucho commanders to enter the hacienda, get as many animals as they wanted, and leave. They did not bother to give the owner a receipt for the livestock, "neither did the landowners dare to ask for one, nor there was any order to give them any," according to one witness. Bustamante argued that Güemes was particularly vicious with him and his family as they had staunchly opposed his election as governor of Salta, and kept opposing his policies ever since. He also recalled that the gauchos knew few limits in their actions:

Those who have not forgotten the sad history of those wretched times should remember very well how disorderly, informal, and burdensome those exactions were. They would also remember the common fact that some landowners were forced to surrender their estates, leaving them under the direction of any Gaucho officer that would demand it. Everybody, even common soldiers, deemed to be authorized to force the owners out of their estates, without any further explanation or documents apart from the command and will of the Colonel, General, and Governor. ${ }^{46}$

Bustamante was speaking from personal experience. In fact, in 1816 some gaucho tenants on his hacienda Rio Blanco brought him before the authorities for calumny. The gauchos reported to their military officers that Bustamante had made groundless accusations against them for stealing cattle and horses from his hacienda. He had also threatened to expel them from his property without any compensation for their crops. All the gauchos involved in the case agreed that Bustamante had treated them with contempt and rudeness. The main plaintiff, Sergeant Francisco Santa Ana relayed to the authorities that Bustamante had said to him, "[N] ow you believe you are Gods because you are Gauchos... You are eating the meat you steal, and riding horses you take away". The other plaintiffs, gauchos Pedro and Raimundo Palala, and Raimundo Aramayo, all tenants of Bustamante on his hacienda, supported Santa Ana's complaint. Aramayo added that Bustamante warned the gauchos that "times would change and then, where would the Gauchos and Commanders go?"47

This episode is is a fascinating example of the kind of challenge to elite power and social standing prompted by popular mobilization in northern Argentina. In fact, poor tenants' bringing their landlord before the authorities was something unheard of before the revolution.

Land occupation seems to have been another form of gaucho action against the elite. In 1822 two landowners of Salta reported the governor that the gauchos on their haciendas had not paid rent for many years. The priest José Gabriel González de Hoyos, owner of hacienda Alemania located on the mountainous area of Calchaqui valley to the west of the province informed Güemes in 1820 that the gauchos in his hacienda were not paying rent. Moreover, the gauchos had made his lands a gathering and grazing point for their livestock knowing that they would not have to pay any fee to the owner. Another landowner, the priest Juan Manuel Tejada complained about gauchos' refusal to pay rent in his hacienda Cerrillos, two miles from Salta. Tejada had not collected the rent for six years, since 1816, and had witnessed the gauchos taking over the land piece by piece, so that "they have left me only the House, the Vineyard, and the Orchard." As he put it, he was reduced to the status of nominal owner 
AHBS, 1822, "Arrendamiento de los Gauchos,"

f. 7-7v.

49

AHBS, 1822, "Arrendamiento," f. 12-12v.

50

AHPJ, DV, Zegada Papers, 11 June 1815. Similar expressions can be found in GORRITI, Op.Cit., p.53-54, URIBURU, Op.Cit., p.720-21, PAZ, Memorias, p.344.

AGN, VII, TSB, III, 138
So far the Gauchos have become the legitimate and true owners of my lands leaving me only as a virtual possessor. They [have not paid] rent in work or money, nor they have given their master the least acknowledgement of his dominion. ${ }^{48}$

Although Tejada acknowledged that the gauchos should be compensated for their sacrifices during the war, he still thought the landowners had the right to collect rent as they supported the gauchos materially. Thus he asked the government to order the gauchos to pay at least half of the annual rent of six to twelve pesos. But, even to determine how much each gaucho owed the landowner was an impossible task, as they had taken over so much land within his estate that he could not identify individual plots. ${ }^{49}$

Actions such as these probably occurred more frequently than they were documented. They reinforced the elite's perception of the gauchos as outlaws protected by military power. The elite increasingly portrayed the gauchos as arrogant, insolent, and unruly. As landowner Miguel Antonio de Sarasivar put it in a letter he wrote in 1815 wrote to his fellow Julián Gregorio de Zegada

all men [in the countryside of Jujuy]...call themselves Gauchos, and even the most ridiculous among them speak with more authority than a General. ${ }^{50}$

\section{Final Remarks}

The War for Independence brought about massive rural mobilization to the northernmost provinces of Río de la Plata, Salta and Jujuy. Protected by the extension of military jurisdiction (fuero) and exempted from paying rent as compensation for their services gauchos posed a real threat to the power of the landowning elite. Arrogance, intimidation, seizure of livestock, and land occupations were actions commonly taken by the gauchos which had been unheard of before the war. These actions seem to have been the blueprint for new social relations that challenged long-held colonial hierarchies and deference. The gauchos considered the status thus acquired as a just recompense in return for their services in the war effort. The elite viewed these actions in a very different light. To them gauchos were arrogant rogues who committed the ultimate affront: to challenge elite power. Teodoro Sánchez de Bustamante expressed the elite's view of Güemes and his gauchos by disdainfully calling the caudiIlo's regime "a disheveled administration."

Challenged at the core of their power, the beleaguered elite could only hope for the war to end and with it the dreaded reign of the gauchos.

\section{Bibliography}

CHASTEEN, John Charles Chasteen. Heroes on Horseback. A Life and Times of the Last Gaucho Caudillos, Albuquerque: University of New Mexico Press, 1995.

CONI, Emilio A., "Los distintos significados del vocablo 'gaucho' a través de tiempos y lugares". Boletín de la Academia Nacional de la Historia XV, 1941, p.309-330.

CORNEJO, Atilio. Historia de Güemes. Salta, 1940.

DE LA FUENTE, Ariel. Children of Facundo. Caudillo and Gaucho Insurgency During the Argentine State-Formation Process. Durham: Duke University Press, 2000.

FRADKIN, Raúl 0. (ed.). ¿Y el pueblo dónde está? Contribuciones para una historia popular de la Revolución de independencia en el Río de la Plata. Buenos Aires: Prometeo, 2008. 
FRADKIN, Raúl and GELMAN, Jorge (eds.). Desafíos al orden. Política y sociedades rurales durante la Revolución de Independencia. Rosario: Prohistoria, 2008.

FRASQUET, Ivana (ed.). Jamás ha llovido reyes del cielo. De independencias, revoluciones y liberalismos en Iberoamérica. Quito: Universidad Andina Simón Bolívar, 2013.

FRIAS, Bernardo. Historia del General Martín Miguel de Güemes y de la Provincia de Salta, o sea de la Independencia Argentina [1902]. Buenos Aires: Plus Ultra, 1972.

GARAVAGLIA, Juan Carlos; GELMAN, Jorge D. Rural History of the Río de la Plata: 1600-1850. Results of a Historiographical Renaissance. Latin American Research Review 30 (3), 1995, p.75-105.

GOLDMAN, Noemi; SALVATORE, Ricardo (eds.). Caudillismos Rioplatenses. Nuevas miradas a un viejo problema. Buenos Aires: EUDEBA, 1998.

GULLÓN ABAO, Alberto. La Frontera del Chaco en la Gobernación del Tucumán (1750-1810). Cádiz: Universidad de Cádiz, 1993.

HALPERIN DONGHI, Tulio. Revolución y guerra Formación de una elite dirigente en la Argentina criolla, Buenos Aires: Siglo XXI, 1972. . El surgimiento de los caudillos en el marco de la sociedad rioplatense postrevolucionaria. Estudios de Historia Social 1, 1965, p.122-127.

HUBER Evelyn and SAFFORD, Frank (eds.). Agrarian Structure \&t Political Culture. Landlord \&t Peasant in the Making of Latin America. Pittsburgh: University of Pittsburgh Press, 1995.

LYNCH, John Lynch. Caudillos in the Hispanic World, 1800-1850. 0xford: Oxford University Press, 1993.

MADRAZO, Guillermo. Hacienda y encomienda en los Andes. La puna de Jujuy bajo el Marquesado de Tojo, siglos XVII-XIX. Buenos Aires: Fondo Editorial, 1982.

MATA, Sara Emilia. Los gauchos de Guemes. Guerras de Independencia y conflicto social. Buenos Aires: Sudamericana, 2008. Tierra y poder en Salta. El noroeste argentino en vísperas de la independencia. Sevilla: Diputación de Sevilla, 2000.

MCALISTER, Lyle. The "Fuero Militar" in New Spain, 1746-1800. Gainsville: University Presses of Florida, 1957.

SAFFORD, Frank. The Problem of Political Order in Early Republican Spanish America. Journal of Latin American Studies 24 (Quincentennary Supplement, "The Colonial and Post-colonial Experience"), 1992.

WOLF, Eric; HANSEN, Edward. Caudillo Politics: A Structural Analysis. Comparative Studies in Society and History 9(2), 1967.

Referências Documentais

ARCHIVO GENERAL DE LA NACIÓN (Argentina) [AGN]. Sala IX (Salta, Jujuy), Sala X (Salta, Jujuy), Sala VII Teodoro Sánchez de Bustamante Papers (TSB).

ARCHIVO HISTÓRICO DE LA PROVINCIA DE BUENOS AIRES. Cedulario de la Real Audiencia de Buenos Aires, La Plata: AHPBA, Vol. 3, 1938.

ARCHIVO HISTÓRICO Y BIBLIOTECA DE SALTA (AHBS)

ARCHIVO HISTÓRICO DE LA PROVINCIA DE JUJUY (AHPJ). Miguel Angel Vergara Documents, Zegada Family Papers.

ARCHIVO DE LOS TRIBUNALES DE JUJUY (ATJ)

CAILLET-BOIS, Ricardo (ed.). Estatutos, Reglamentos y Constituciones Argentinas (1811-1898). Buenos Aires: UBA-FFyL-Instituto de Historia Argentina, 1956. 
GARCÍA CAMBA, Andrés. Memorias del General García Camba para la historia de las armas españolas en el Perú, 1809-1821, Madrid: Editorial América, n/d, I, p.314-315.

GRAANER, Jean Adam. Las Provincias Unidas del Río de la Plata en 1816 (Informe dirigido al Príncipe Bernadotte) [1817]. Buenos Aires: El Ateneo, 1949, p.72-73.

GÜEMES, Luis (ed.). Güemes documentado (vol. 7). Buenos Aires: Plus Ultra, 1972.

MITRE, Bartolomé. Historia de San Martín y de la emancipación americana. Buenos Aires, 1887, I, 263-264.

PAZ, José María. Memorias póstumas del General José María Paz. Madrid: Editorial América, n.d.

ROJAS, Ricardo (ed.). Archivo Capitular de Jujuy, [AC], Jujuy, 1913-1943. (4 volumes)

URIBURU, Dámaso de. Memorias. Biblioteca de Mayo. Colección de Obras y Documentos para la Historia Argentina. Memorias, Autobiografías, Diarios y Crónicas. Buenos Aires: Senado de la Nación, 1960, vol. I.

VERGARA, Miguel Ángel (ed.). Papeles de Gorriti. Jujuy, 1936. 